\title{
Logistics Implications in the South African Coal Mining Industry Supply Chain
}

\author{
Dr. Ken Mathu \\ Vaal University of Technology
}

\author{
Doi:10.5901/mjss.2014.v5n20p503
}

\begin{abstract}
The importance of the South African coal mining industry goes back to more than 100 years. However, the logistics role of the of the coal supply chain since early 1920s when coal started replacing hydro power as a primary source of energy continues to be of significance to socio-economic attributes and of concerns in environmental impacts. The coal transportation modes are conveyor belts, rail, road and water. The South African coal serves both domestic and export markets. The leading industry players are the five leading international resources companies which produces over $80 \%$ of the commodity in the country. The companies are BHP Billiton, Anglo American, Xstrata/Glencore, Sasol and Exxaro and they jointly own Richards Bay Coal Terminal which is also the leading coal export terminal in the world. The other $20 \%$ of coal is produced by the black economic empowerment companies also known as junior miners. The domestic coal is mainly used for the generation of electricity, production of synthetic-fuels/petrochemicals, as a catalyst in the heavy industries and for cooking and space heating at homes. The coal logistics benefits the communities where the mines and consumers are located, but it also has adverse effects on the environment. These factors are some of the major logistics implications in the South African coal supply chain.
\end{abstract}

Keywords: logistics, coal supply chain, transport, coal-mining, socio-economic, environment

\section{Introduction}

The history of coal-mining in South Africa spans over 100 years. On discovery, coal was used with ease for cooking and space heating. As its commercial significance grew, the coal-mining industry supply chain visibility started emerging and its impact experienced in industrial, agricultural and in social sectors. On replacing the hydro power in early 1920s as the primary source of energy, the logistics role in the supply chain started gaining prominence.

The coal supply chain focus areas are the mines, coal-stockpiles, beneficiation and transportation to the customers who in most cases are the major consumers. The coal transportation modes are dictated by the type of users and location. The bulk of the South African coal is consumed by the coal-fired-power stations and most of them were built next to the coal mines for the ease of transportation costs, hence, the short distance involved between the mines and the power stations facilitate the use of conveyor belts. Road transport is used to supplement coal supply to the power stations which are already being supplied via conveyor belts as the respective mines reserves are presently unable to meet the power stations' demand as a result of depletion. The coal delivery to the heavy industries which has no rail connection tippler facilities and homes is done by road. However, the rail transport is predominantly used for export coal to the terminal from where it is shipped by sea to the export markets in Europe and Asia. A limited number of power stations have tipplers which allow coal supply by rail.

Coal-mining in South Africa is predominantly by the five international resource companies which produce over 80\% of the total coal mined in the country. These companies are BHP Billiton, Anglo American, Xstrata/Glencore, Sasol and Exxaro and they jointly own the Richards Bay Coal Terminal (RBCT) which is located along the Indian ocean coast of Kwa-Zulu Natal Province. RBCT is also the biggest coal export terminal in the world with annual capacity of $91 \mathrm{mt}$.

The market segmentation is $75 \%$ domestic and $25 \%$ export. Coal use for the domestic market is dominated by the generation of electricity, production of synthetic liquid-fuels/petrochemicals, a catalyst in the heavy industries and cooking and space heating at homes. The conveyor belts, road and rail are the transportation modes used for the domestic markets. The export coal is transported from Mpumalanga coalfields to RBCT and then transported by sea to the export destinations in Europe and Asia.

The inbound and outbound logistics in the coal supply chain significantly impacts on the gross domestic product (GDP) and has strong socio-economic attributes to the communities living in the coal-mining and coalconsumption/transformation areas. However, the environmental implications is of major concern, as it is almost certain presently, that the carbon emissions into the atmosphere from coal combustion contributes significantly towards the global climate change. In South Africa environmental degradation occurs in Mpumalanga Province, where most of the 
coal-fired power stations are located, as heavy trucks transport coal to the power stations by road causing road damage and air/noise pollution. These are some of the most significant coal logistics implications as the world pursues sustainability in energy supply now and in future.

\section{Problem Statement}

The problem statement for the study was to establish the logistics implications in the South African coal supply chain in socio-economic attributes and environmental impacts.

\section{The Purpose of the Study}

The purpose of the study was to establish the positive logistics implications in socio-economic attributes to the community and the negative implications impacting on the environment. The coal supply chain role players' corporate social responsibility and measures towards better environmental management were explored.

\section{Methodology}

The study adopted a qualitative research paradigm. According to Cooper and Schindler (2008: 162-168) the outcome of the qualitative interview depends very much on how the researcher prepares the participants for the interview. 'Qualitative research has substance, gives insight, shows sensitivity and is unique in conceptualisation, yet grounded in data' (Corbin \& Strauss 2008: 302).

Various aspects covered by this study included selection of participants, undertaking the interview, feedback on the interview for validity/reliability and facilitating data collection in a recorded form using an audio data recorder and field notes. Citing Goddard and Melville (2005: 49) the researcher must not direct the participant's answer through his tone of voice or rephrase the research question. Research design involves activities of 'collecting and analysing data, developing and modifying theory, elaborating or refocusing the research questions, identifying and addressing validity threat' (Maxwell 2005: 2).

The selection and profile of the participants was done using purposive sampling process. The process aimed to enhance understanding of the selected people and groups as they were selected for a specific purpose, task or expertise in research. 'The researcher should be in a position to expound the use of purposive sampling in order to instill confidence and validity for research findings' (Devers \& Frankel 2000: 264-265). The participants for this study were the top professionals who were also involved in decision making in their respective organisations in order to provide credibility to the study. There were 14 respondents earmarked for this research and 13 of them responded: 12 respondents were interviewed at their work place while 1 respondent provided a telephonic interview. The interview population of the 13 respondents comprised 4 Chief Executives and 9 senior professionals in the mining and affiliated industries nominated by their respective chief executives.

\subsection{Sample and Procedures}

The researcher is required to obtain permission from gate-keepers of the target institutions in order to obtain access to individuals and institutions (Ehigie \& Ehigie 2005: 622-623). The permission to conduct research either oral or written is paramount (Cooper \& Schindler 2008: 37). The objectives for the research were addressed at the initiation stage as the researcher approached the institutions' gate-keepers by stipulating the value proposition for the study, purpose and ethical considerations that also addressed the 'informed consent' (admissibility for research process).

Some of the critical requirements for a researcher are skills in negotiation and relationship building to be able to successfully access the prospective respondents. In this study, the researcher approached the selected participants via telephone and e-mail and briefed them on the value proposition for the project. Since the respondents were senior executives in their respective companies, some of them responded directly, while the others responded through their personal assistants. In two occasions the researcher was invited to give a presentation on the purpose of the research before the consent to interview was granted. A research introduction letter from the Vaal University of Technology formed part of the presentation. The content of the letter included the introduction of the researcher, confidentiality undertakings and the use of audio digital data recorder for recording the interviews. 


\subsection{Data Analysis}

The use of the audio digital data recorder and the field notes were the methods used for data collection. The collected data was transcribed and content analysis was used for the translation and analysis. The emerging themes and subthemes were recorded and evaluated to establish constraints that exist in the industry that would be resolved by the public-private partnership model.

\subsection{Reliability and Validity (Measures of Trustworthiness)}

Triangulation method was used to check the reliability and validity of data from this study. The process involved were comparing data from the interviews, feedback from the participants and from the literature. The researcher's field notes articulated the respondents' output. Some participants also provided written clarifications of some of their contributions after the interview. 'Multiple sources lead to a better understanding of the phenomena being studied' (Willis 2007: 219). Triangulation enhances validity and richness of data by looking at issues from different angles (Lee \& Lings 2008: 239).

\subsection{Ethical Procedures}

According to Eriksson and Kovalainen (2008: 68) research is vulnerable to 'lies, fraud and wrong-doing' hence, ethical adherence is paramount. The ethical issues for this study were addressed through the research introduction letter from the Vaal University of Technology addressed to those participants who had accepted the invitation for the interview. The letter provided confidentiality, anonymity and use of pseudonyms between the respondent and the researcher.

\section{Results}

Table 1: Themes and sub-themes emanating from the interviews

\begin{tabular}{|c|c|}
\hline Themes & Sub-Themes \\
\hline $\begin{array}{l}\text { Coal: origin, quality, business model, production, consumption and } \\
\text { trade (economic benefits/welfare of employees and communities) }\end{array}$ & $\begin{array}{l}\text { - Coal and its properties, reserves, production, consumption } \\
\text { and trade } \\
\text { - Employee satisfaction } \\
\text { - Community welfare } \\
\text { - Environmental impact }\end{array}$ \\
\hline Legislative environment (MPRDA, NEMA, NERSA) & $\begin{array}{l}\text { - MPRDA Act of } 2002 \\
\text { - NEMA Act of } 1998 \\
\text { - NERSA }\end{array}$ \\
\hline $\begin{array}{l}\text { Role players: coal mines (private), Transnet- rail (public), Chamber } \\
\text { of mines (private) }\end{array}$ & $\begin{array}{l}\text { - Coal-mines } \\
\text { - Transnet (rail transport) } \\
\text { - Chamber of mines (advisory roles) }\end{array}$ \\
\hline $\begin{array}{l}\text { Transport infrastructures: conveyor belts, rail, road, water. } \\
\text { Road damage in power stations area of Mpumalanga Province }\end{array}$ & $\begin{array}{l}\text { - Rail for export coal and less for domestic transport } \\
\text { - Road damages in power station areas } \\
\text { - Conveyor belts for collieries tied to power stations }\end{array}$ \\
\hline Ownership of the rail/TFR-TRANSNET & - State ownership of rail hinders maximum collaboration \\
\hline Skills shortage across the industry & $\begin{array}{l}\text { - Mining engineers, mangers, artisans, mining equipment, } \\
\text { rolling stock, trains, old rail gauge }\end{array}$ \\
\hline $\begin{array}{l}\text { Environmental issues: pursuing green initiative, social } \\
\text { responsibility. Commitment to "cradle to grave" philosophy of } \\
\text { green environment } \\
\text { Dilapidated coal mines in Mpumalanga Province }\end{array}$ & $\begin{array}{l}\text { - Environmental degradation: carbon emissions, dust, noise } \\
\text { and diesel pollution } \\
\text { - Coal transport by road } \\
\text { - "cradle to cradle" and "cradle to grave", product reuse, } \\
\text { recycle rehabilitation (soil, water, mines) }\end{array}$ \\
\hline
\end{tabular}

Source: Mathu (2011: 222-223)

Table 1 indicates the themes and sub-themes that emanated from the study. The themes focus on the history and properties of coal; legislative environment; coal supply chain role players; transport infrastructures; rail ownership, skills shortage and environmental impacts. Both the themes and sub-themes are discussed hereunder: 


\section{Discussion}

The major themes that emerged from the interviews with the respondents were actually the seven major constraints experienced in the South African coal mining industry supply chain. The constraints covered a wide range of issues including coal and its properties; legislative environment; industry role players (government, public and private enterprises); transport infrastructure, ownership of TFR-Transnet; skills shortage and environmental issues. The respondents were professionals and decision makers from across the industry as elaborated herewith:

\subsection{Coal and Its Properties}

Coal is a fossil fuel and a primary source of energy in South Africa. Coal is formed from accumulation of dead vegetation over many years, undergoing a slow decaying process turning into peat that transforms into coal seams (Anglo Coal 2007: 47). According to Abbott, Apostolic, Goodman, Hortsman, Jenner, Jewell, Labhart, Maragos, May, Sunderman, Parke, Stein, Wengler and Went (2009: 53) the slow formation process that takes millions of years make coal a nonrenewable source of energy.

South African coal is associated with the Karoo rock formations which extend over the present day Free State, Mpumalanga, Limpopo and Western Natal. The chemical composition and properties of coal determine its usage. South African coal is less reactive, harder and has lower sulphur content compared to coal from the Northern hemisphere. The bulk of South African coal is bituminous or thermal grade suitable as fuel for electricity generation and anthracite suitable for metallurgical plants (Lang 1995: 20).

Carbon contents determine the calorific value (heat value) and it is used in the classification of coal (Abbott et al., 2009: 53) viz:

\subsubsection{Lignite Coal}

It is the lowest ranked coal with carbon content of $25-35 \%$ and it is mainly used in power stations to generate electricity.

\subsubsection{Sub-bituminous Coal}

It has higher calorific value than lignite, contains $35-45 \%$ carbon and its main use is also as fodder for the power stations.

\subsubsection{Bituminous Coal}

It has higher calorific value than sub-bituminous, contains $45-86 \%$ carbon and it is used for power generation and in the metallurgy industry as 'coke' for the production of iron and steel.

\subsubsection{Anthracite Coal}

It is the highest ranked coal in quality and it is hard, glossy and black. It possesses the highest calorific value, contains $86-97 \%$ carbon and it is mainly used for residential and commercial space heating.

\subsubsection{Graphite Coal}

It possesses the same quality with anthracite and it is mainly used in pencil making and as a lubricant when powdered.

\subsection{South African Coal Reserves}

South Africa has coal reserves of approximately 30408 million tons, the sixth largest coal reserves in the world. The coal reserves are found in Mpumalanga, Free State, Limpopo, Kwa-Zulu Natal and Limpopo coalfields (DMR 2009:44).

The South African coalfields are mainly concentrated in the Mpumalanga coalfields where most of the coal-fired power plants are situated. The 650 kilometres rail line that transports coal to the Richards Bay Coal Terminal for export also runs from this area. Mpumalanga Province presently produces in excess of 70 percent of the South African coal, but the reserves are currently running low (depleting). It is estimated that from around 2020, coal mines in the Mpumalanga area will start relocating to the Waterberg coalfields in Limpopo Province which has abundant, untapped coal reserves 
(Chamber of Mines 2009:27).

There are 73 collieries in South Africa (Prevost 2009: 27). Most of them are owned by the five leading mining companies that produce over 80 percent of coal in the country and the others are owned by smaller black economic empowerment (BEE) mining companies or junior miners that contribute the remaining $20 \%$. The national distribution of the collieries comprises: Free State (2); Gauteng (1); Kwazulu-Natal (7), Limpopo (2) and Mpumalanga (61).

\subsection{South African coal mining business model}

There are two types of business models for coal mining in South Africa namely domestic and export models. The domestic model has three stages which comprises the mining process, transportation to the domestic customers/consumers and the processes at the customers' facilities who are usually the consumers. The export coal model also has three stages which are mining process, transportation to the coal export terminal by rail and shipping to overseas customers by sea. The export terminal is at Richards Bay along the Indian ocean coast of Kwa-Zulu Natal.

The following figure shows the South African coal mining business model depicting both domestic and export markets.

Figure 1: The South African Coal Mining Business Model for domestic and export markets

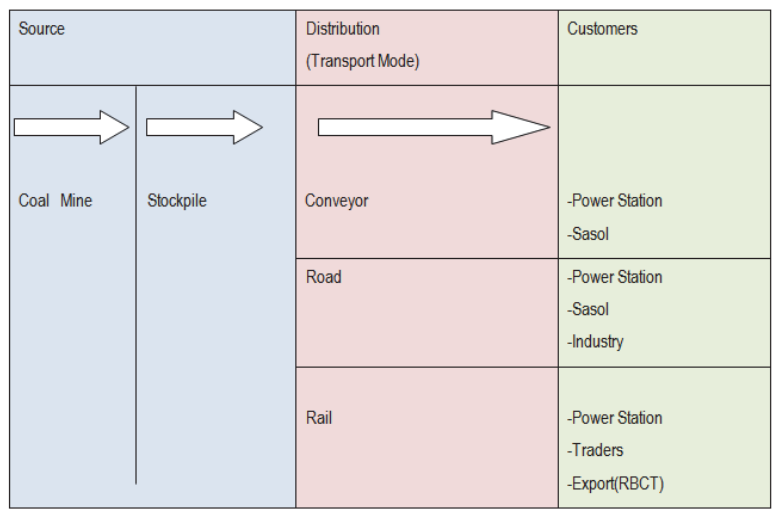

Source: Mathu 2011: 63

The South African coal mining business model has three main stages: source (coal mining/ beneficiation), transportation (mode of transport used) and customers/ consumers.

\subsubsection{Stage 1: Mining}

The mining process involves removal of overburden on the top of the mine and coal that is brought to the surface mixed with rocks. The rocks are sorted from coal and delivered to a dump site. Coal free of rocks is stockpiled on a site allocated near the mine.

\subsubsection{Stage 2: Distribution (Transportation)}

Three types of transport modes are used for local distribution to the customers conveyor, rail and road while rail and ship are used for export. The power station coal is delivered direct from the stockpiles and does not go through the beneficiation process. The bulk of the power station coal is delivered via conveyor belts. The rest is delivered by road and rail. The export coal is taken through the beneficiation process and delivered to the export terminal by rail. The coking coal for metallurgical industry, cement industry, aluminium smelters and for the traders is delivered by road and rail. 


\subsubsection{Stage 3: Customers}

The domestic customers for coal are the power stations, SASOL, industry and traders while the export customers abroad are the power stations and industry.

\subsubsection{Coal Logistics}

Logistics complements supply chain through strategy, design and execution. Supply chain design entails strategic functions involving the chain members, its length, breadth, locations systems and relations (Waters 2007: 42). The holistic logistics functions as in the coal supply chain comprises: procurement and purchasing; inward transport (inbound logistics); receiving; stockpiling; stock control; material handling; outward transport (outbound logistics); reverse logistics and communication (coordinating flow of information and money).

Purchasing is a very important logistics role and Porter (1985: 39:40) stated its five pillars which include inbound logistics, outbound logistics, operations, marketing/sales and services. These pillars are also applicable in the coal logistics.

The transport role in coal logistics includes product movement (coal), stockpiling, inbound logistics (supplies to the mining company), outbound logistics (coal deliveries to customers/consumers), Third-Party logistics (3PL) (outsourced transport transporting coal to customers/consumers) and Fourth-Party logistics (4PL) (outsourced management services such as (IT) (Waters 2007: 71). The broad application of these logistics functions constitutes their implications in the coal supply chain.

\section{Coal Production}

The South African coal mines are predominantly situated in the Mpumalanga coalfields. The future of South African coal mining is in Waterberg coalfields in the Limpopo Province after depletion of coal reserves in Mpumalanga deteriorates around 2020. Mining companies have already started identifying their relocation to Waterberg. The giant Medupi power station is located there and on completion it will be supplied by Exxaro mining company (Eskom 2011: 88)

A report from Eskom indicated that mining development has stalled in the last ten years. It also indicated a projection of up to 2018 comprising 43 new mines at an estimated cost of about R 100 billion and raising the 2008 national production estimate of $270 \mathrm{mtpa}$ to $370 \mathrm{mtpa}$ by 2018 . Those mines would be developed by the existing leading mining groups in the industry and just a few to be developed by the Black Economic Empowerment companies (Eskom 2009: 15).

South African coal production has stagnated since 2004 while consumption by Eskom has risen to meet the continued rising power demand. The scenario puts Eskom in competition with the other domestic consumers, resulting in price hikes and this has forced Eskom to use discarded coal from the big coal exporters in order to meet their requirements. The demand will continue to outstrip supply for some time until new coal mines come on stream (Smuts 2008:36). Presently, Eskom is building two giant coal-fired power stations Medupi and Kusile which will be completed in stages from 2014 (Eskom 2011: 88-89).

\section{Coal Consumption}

There are two categories of coal usage in South Africa namely domestic consumption and export markets. The domestic consumption is predominantly by Eskom power stations for the generation of electricity, Sasol for transformation into synthetic fuels and petrochemical products, steel and cement industries, aluminium smelters and homes for various applications.

\subsection{Coal for the Generation of Electricity (Eskom)}

Eskom is a South African government-owned power utility company that consumes the bulk of coal produced in the country as fuel for the generation of electricity through its current 13 coal-fired power plants which generate 88 per cent of the national electricity (Eskom 2009: 226). Eskom is one of the top 10 utilities in the world by generation capacity (Eskom 2009: iii). This is an indication of the size and capacity of the utility. The company's electricity generation mix comprises coal, hydro, pumped storage and some imports. This brings the total nominal capacity to 44193 megawatts (MW) (Eskom 2009: iii). 
Eskom consumes approximately 50 percent of the coal produced in South Africa and approximately 66 percent of the total domestic coal consumption. Its consumption in 2011 was 124.7 million tons of coal (Eskom 2011: 11). The power crisis of 2007/2008 impacted heavily on the company and on the economy as well as communities. The coal stockpile at the power stations had deteriorated due to poor coal logistics, among other factors. As a result, Eskom was forced to step up coal transport by road to the detriment of the environment in the Mpumalanga area where most of the coal-fired stations are located (Bischoff 2009: 100).

This study established during the interviews that coal transportation is done 70 percent by conveyor belts, 24 percent by road and 6 percent by rail. The future plan is to reduce road transport to below 6 percent and increase rail transport to more than 24 percent. Eskom is under pressure to control costs and rail transport is viewed as being more economical, safer and sustainable (Eskom PE Division 2008: 12).

Eskom uses a network of national grid to transmit and distribute power directly or through municipalities. The national grid comprises 395 419km power lines (Eskom 2011: 169).

\subsection{Coal for Production of Liquid-Fuels and Petrochemical Products (Sasol)}

South African Synthetic Oils (Sasol) is a South African public company founded in 1950 and has international operations in a number of countries. The company manufactures a wide range of petrochemicals and synthetic fuels. It supplies a third of South Africa's liquid fuel requirements. It is also the country's single largest industrial investor, as well as the largest chemical feedstock producer. Its contribution to the Growth Domestic Product (GDP) is 4.7 percent amounting to R 40 billion a year (Sasol 2012: 11)).

'Sasol's primary business is based on coal-to-liquid (CTL) and gas-to-liquid (GTL) technologies using FischerTropsch synthesis. CTL and GTL plants convert coal and natural gas respectively into liquid fuels. The company has GTL projects countries such as Qatar, Nigeria and china. The Fischer-Tropsch synthesis has adverse effect in massive emission of carbon dioxide into the atmosphere. Indeed, the company's Secunda plant is one of the world's single largest emitter of carbon dioxide.' (Sasol 2008: 83).

\subsection{Coal Use in Industry and Homes}

Coal is transformed under high temperature of approximately 1000 degrees Celsius into coke for use as a reducing agent fuel in the smelters in blast furnaces (Crawford 1993: 5). It is used for cooking and space heating in homes and industries (Chamber of mines 2009: 25).

\section{Coal Trade}

The South African coal trade covers both domestic and export markets. The domestic market is dominated by Eskom, Sasol, steel and cement industries, aluminium smelters and domestic market comprises 75 percent of total coal produced in the country. The remaining 25 percent is exported. Taking example of 2008, the distribution of the South African coal market estimated at 252.2 (Mt) was $194.3 \mathrm{Mt}$ for the domestic market and $57.9 \mathrm{Mt}$ for export. A further distribution ratios were as follows: power generation - Eskom (124.35mtpa), Sasol (44mtpa), industries (9mtpa), merchants (12.25mtpa) and exports (57.9mtpa) (Prevost 2008:7).

However, coal trade has stagnated in the last decade due to limited capacity of shipment from Mpumalanga coalfields by Transnet Freight Rail (TFR) for reasons such as inadequate wagons and other operational factors. According to Transnet 2013 Annual Report, TFR capacity reached 81mtpa and the projection is $97.5 \mathrm{mtpa}$ in 2020 (Transnet 2013: 140).

The local coal price per ton Free on Rail (FOR) averaged R 150.40 per ton in 2008, a 40.5 percent increase on the 2007 price. The average export price FOB (Free on Board) was R 704.62 per ton in 2008, a 94.5 increase over the 2007 price. The rise in local price was mainly attributed to higher mining costs resulting from higher input costs. Presently, the price of coal is USD 82.31 which is equivalent to ZAR823.10 at the exchange rate of R10 for 1USD (Coal Trader 2013: 1).

\section{Legislative Environment}

This study concentrated on the legislative environment from the South Africa's Department of Mineral Resources, Department of Water and Environmental Affairs and the National Energy Regulator of South Africa. 


\subsection{Department of Mineral Resources (DMR)}

The Department of Mineral Resources (DMR), previously Department of Minerals and Energy (DME), uses the Mineral and Petroleum Resources Development Act (MPRDA) - Act 2002 (Act No. 28 of 2002) that was promulgated in April 2004 in the administration of the mining industry (Government Gazette 2006: 3).

\subsection{Department of Water and Environmental Affairs (DW\&EA)}

The Department of water and environmental affairs (DW \& EA) ensures that mines has environmental management plan $(E M P)$ based on the principle of integrated environmental management as provided by the National Environmental Management Act (Act No. 107 of 1998) NEMA (Government Gazette 2010: 3).

\subsection{National Energy Regulator of South Africa (NERSA)}

The National Energy Regulator of South Africa (NERSA) is the precursor National Energy Regulator (NER) established in October 2005 to regulate the energy sectors in electricity, piped gas and petroleum. This study concentrates on the regulation of energy derived from coal which comprises electricity and synthetic liquid-fuels (NERSA 2009: 5).

Established under Section 3 of the National Energy Regulator Act, 2004 (Act No. 4 of 2004), NERSA's mandate is to maintain a delicate balance between the regulated energy industries, users and consumers (NERSA 2008:16). The regulatory body advises the electricity and other energy institutions on the tariffs they charge the consumers and arbitrates grievances between the consumers and the energy distributors, among other roles. This ensures that the end users and consumers receive appropriate service and pay the correct rates recommended by the government (NERSA 2009:11-15).

\section{Transport}

The modes of transport in the South African coal industry supply chain are conveyor belts, rail, road and marine or water transport.

\subsection{Conveyor belts}

In the South African coal mining industry, conveyors are used to transport coal to a number of power stations in the Mpumalanga area as a number of them are built next to the coal mines. The coal-fired power plants are designed with a coal mine next to them for the ease of supplying coal in a system called a 'tied-colliery' contract These are long-term contracts meant to ensure coal supply security to the power stations. Even the two new coal power stations currently under construction are designed on this model with 40 years long-term coal supply contracts (ESKOM 2009: 65).

However, this study has established a few instances where this model is not applicable, for example in the case of Majuba power station whereby the coal mine designated to supply the station could not be used due to geological problems. So the power station's coal requirement is delivered from other mines by road and rail. Presently, some of the coal mines in the Mpumalanga coalfields are affected by coal depletion and are not able to produce enough coal to meet the power stations' capacity so road and rail transportation are used to deliver the extra coal from outside coal mines. For instance, the mine that supplies Tutuka power station produces only $50 \%$ of the power plant's coal capacity so the rest has to be delivered from other mines by road and rail (ESKOM 2009:226).

\subsection{Rail Transport (Transnet/TFR)}

The South African rail network is operated by the state corporation TRANSNET through one of its business units Transnet Freight Rail (TFR). 'The TFR uses the national rail network comprising 22000 kilometres for freight transportation of which 1500 kilometres comprises heavy haul lines for export coal and iron ore. The rail network connects the ports to the hinterland of South Africa and the Sub-Sahara region. Services are primarily provided to customers in the mining, manufacturing, agriculture, forestry, automotive and intermodal sectors of the economy across the border trade and six African countries' (TRANSNET 2009:124).

South African rail freight is determined by the structural change in the economy from "a mining to a manufacturing focus". 'The main cost drivers in the rail freight industry include the long distances of transporting goods (minerals) from 
the mines to the ports and the massive labour costs as a percentage of the total operating costs. However, TRANSNET has an organised and efficient way of moving coal, iron ore and other resources, but the process of moving manufactured goods is still inefficient and unreliable. Mining haulage involves transportation of coal, iron ore, manganese, chrome, timber and other mineral resources. Moving of manufactured goods involves transportation of cement, fuel, chemicals and fast-moving consumer goods (FMCGs)' (DoT 2006: 50).

'The South African Department of Transport (DoT) Strategic Plan for 2010 to 2013 aims to make freight among other types of transport efficient and sustainable to the economy. This would enhance the Accelerated and Shared Growth Initiative for South Africa (AsgiSA) through collaboration of infrastructure development in transport, energy, mining, telecommunication, information technology, agriculture and Public Works'. The rail freight focuses on two corridors for mineral transportation namely coal from Mpumalanga Province to Richards Bay, a distance of $650 \mathrm{~km}$ and iron ore from Sishen in the Northern Cape to Saldanha Bay, a distance of 850km (DoT 2010: 2).

According to (TRANSNET 2009:124) the rail freight company focuses on some critical operational issues that include:

- sustained safety improvements;

- executing customer demands;

- locomotive and wagon efficiency improvements;

- review of operational processes to lower costs and the creation of better efficiencies; and

- re-deployment of people-capacity to enhance operational performance, training and better skills to ensure a steady a steady movement towards best practices.

\subsection{Road}

The total land transportation in South Africa comprising the road and the rail usage, accounts for approximately 90 percent of the total transport with road comprising 66 percent of the market share. According to Lane (2010:33), road transport has advantages over the rail in that there is accessibility (road network available in most places), competition (resulting in improved service, reliability, operations, equipment and competitive pricing) and perceived use for crosssubsidisation,

Road freight has a competitive advantage over rail freight as the South African roads are maintained by the government, whereas the state owned corporation TRASNET is responsible for maintaining both the fleet and the rail tracks. South Africa has a national road network of 754600 kilometres. Table 4-1 shows the national distribution of the road types (DoT 2006: 80).

The increased use of coal transportation to the power station in Mpumalanga is detrimental to the environment. This inevitable situation is due to the coal mines in the area experiencing depletion and unable to meet the capacity of the designated power stations. The situation will only improve when new coal mines are established at Waterberg coalfields in Limpopo Province and this will take time as the infrastructure in that area has to be developed first.

\subsection{Marine}

The marine transport in the South African coal mining industry supply chain is only used for export coal and the main export terminal is RBCT.

\subsection{Coal Export Terminal (RBCT)}

The port of Richards Bay is situated 170 kilometres north of Durban on the Indian ocean coastline. It was opened in 1976 and commenced with an export capacity of 10Mtpa. This capacity grew over the years and reached a capacity of 72Mtpa in 2008 (Goussard 2009:8). The capacity reached 76mtpa in 2009 (Prevost 2009: 7) and by 2010 its expansion reached 91mtpa. Richards Bay Coal Terminal (RBCT) is the largest single coal export terminal in the world, exporting more than 69 million tons annually (DMR 2009:47). In 2011 the port exported 65.5mt and 68.3mt in 2012 (Mining Weekly 2012: 1).

RBCT is connected to the coal mines via Transnet Freight rail (TFR) running from Mpumalanga coalfields to Richards Bay terminal along the Indian ocean. The terminal coordinates with the Transnet National Ports Authority (TNPA) for the arrival and departure of more than 700 ships per annum (Coal International 2007: 12). 


\section{Chamber of Mines of South Africa}

The Chamber of Mines of South Africa is a voluntary membership private organisation which was founded in 1889 to look into the affairs of the mining industry. The Chamber liaises with universities and international organisations for mining related research and bridges between the government, labour unions and the mining industry (Chamber of Mines 2009: i).

\section{Skills Shortage (Constraints)}

The need for more coal-fired power stations and new coal mines calls for more skills in technical areas in the supply chain that includes engineering, transportation and equipment operations. According to Wilhelm (2009: 6) estimates, building 40 power stations would require 600 engineers and 2500 artisans.

\section{Environmental Impacts (Constraints)}

All the participants reaffirmed a continuous liability in managing 'green' issues as required by the mining legislation and the willingness of their respective organisations to respond to the requirements. The legislation would ensure control of the dilapidated ownerless coal mines, continuous burning of coal mine dumps, air and water pollution.

The power generation from coal consumes approximately $50 \%$ of the total coal mined in South Africa and the production of synthetic liquid-fuels and petrochemicals consumes 18\%. These energy producing processes are the leading carbon emitters in the country and hope to employ more effective measures in future to control the emissions (Lloyd 2002: 47).

It is estimated that by 2020 South Africa will increase coal production by $75 \mathrm{mtpa}$ and production of clean energy from renewable sources and nuclear would increase tremendously according to the 2010 Department of Energy's integrate resource planning (IRP2). The country has a target of reducing of reducing carbon emissions by $34 \%$ from a business-as-usual scenario in 2020 and 42\% in 2025 (Salgado 2010b: 19).

According to a phenomenon called' Lloyd's Blanket Atmospheric Pollution', a European satellite image above Mpumalanga and Gauteng Provinces indicate a high level of nitrogen dioxide atmospheric pollution due to coal-based electricity generation in the region (Abbott et al. 2009: 87). The future energy generation and consumption from coal sources will require technologies which would control carbon emissions and sustainable modes of transport on land (Resource 2010: 16).

Presently, more than three-quarters of South African carbon emissions come from energy generation and consumption. Therefore, increased energy mix will reduce coal use drastically in order to realize the anticipated target for 2020 and 2025. 'The current coal-fired power stations will be decommissioned by 2025 when their economic life expires. However, the new coal-fired-power stations that will come on stream in future including the two new ones under construction Medupi and Kusile, will use clean coal technology (CCT)' Eskom 2009: 59).

The respondents concurred that the environmental degradation by excessive use of transportation of coal by road would be controlled by building additional rail lines linking the coal mines with the power stations in future. The extensive use of rail transport would also reduce noise and air pollution.

The philosophies of 'cradle to cradle' and 'cradle to grave' according to the respondents, means that companies should manage their products' life cycle in both forward (towards point of sale) and backward (reverse logistics) movements in the supply chain.

\section{The Future of Coal Mining in South Africa}

The future of South African coal mining lies in coalfields which were identified in the past, but were never exploited due to constraints such as the lack of infrastructure, difficult coal mining conditions, high ash content and low calorific value (CV). 'These massive areas include Waterberg, Springbok Flats, Limpopo, Soutpansberg, Tuli, Mabopane, Venda-Pafuri and the Free State coalfields. They contain younger coal compared to that of Mpumalanga coalfields. The Waterberg coalfields alone contain about 3.4 billion tons of coal or 11 percent of South African recoverable coal.' (Prevost 2008: 6-9)

The South African coal mining sector has medium and long-term plans to increase coal production capacity. 'Presently, the industry has R15.5 billion worth of projects underway which could yield about $36 \mathrm{Mt}$ of extra coal production, while also sustaining production at some mines. Another $63 \mathrm{Mt}$ worth approximately R 30 billion is in the final feasibility stage. It is estimated that about R100 billion will be invested in the industry over the next decade if targets are 
to be achieved.' (Chamber of Mines 2009:27).

With the Mpumalanga coalfields being presently overexploited, the future of South African coal production lies in the Waterberg coal fields in the Limpopo Province (Prevost 2010:17). Eskom plans to construct new power stations in the area in future, commencing with the R110 billion Medupi dry-cooled coal power station which is under construction outside Lephalale. The feedstock for the giant power plant of nearly 14.6 million tons of coal per year will be supplied by the Grootegeluk coal mine owned by Exxaro Resources. Another dry-cooled new coal power station with the same capacity Kusile is also under construction near the area and it will be supplied coal by Anglo Coal on completion. Each of the two power stations will have generation capacity of 4500 MW (Eskom 2011: 89-90).

The availability of water is a significant factor in the coal-mining industry. Large volume of water is required for mining, beneficiation and processing purposes (Prevost 2008:11). 'In the case of the Waterberg coalfield, the availability of water is a major inhibiting factor. 'The Matimba power station uses water from Makola Dam outside Lephalale. Presently, more water could become available by raising the level of Makola Dam, but it would not be enough for the earmarked development in the area. A geo-hydrology study is also being carried out to establish the availability of water in the area.' (Van Vuuren 2009:15).

\section{Limitation of the Study}

The study being qualitative had a limitation on the number of participants. A total of 13 professionals from the coal mining industry and the role players were interviewed. Recruiting such high caliber professionals was time-consuming in accessing them and their institutions as explained in the methodology chapter. However, the response by the respondents from the industry was positive (13 approvals out of 14 proposals).

Accessing the industry had other limitations due to its nature as energy industry and energy is a sensitive subject because of its critical role in sustainable development. The institutions in the industry are not easily accessible without convincing reasons and introducing a research topic is not one of the most desired reasons to gain access. However, with skills and patience, it was possible to gain access and to successfully accomplish the project.

\section{Conclusion}

There are several logistics implications in the South African coal mining industry supply chain considering the diversity of the role players from both public and private sectors. Topping the list are contributions towards the growth domestic product, community social welfare and the large number of employees benefitting from the value chain. However, coal logistics implication on the environment is of great concerns. We are living in an era threatened by the global warming due to climate change. One of the causes of climate change is now according to the United Nations over $90 \%$ confirmed to be carbon emissions into the atmosphere from coal combustion from power stations and industries. In South Africa, there is an additional problem of extensive use of road transport for coal to the power stations, resulting in extensive road damages, increased road accidents and air/noise pollution in the Mpumalanga area where most of the coal-fired power stations are located.

\section{Recommendations}

This study recommends implementation of a public-private partnership (PPP) model for the South African coal mining supply chain citing current inadequate logistics integration and collaboration between the state owned rail company Transnet and the privately owned coal mining industry. A PPP model would streamline the coal supply chain operational efficiency and effectiveness. The focus would be on general operational issues and policy implementations.

\subsection{General recommendations:}

- The coal mining industry needs to move from internal focus to cross-enterprise collaborations. Such collaborations would enable industry players to look beyond the profit focus and start seeing the value of cooperation and information sharing with the other members of the value chain.

- An Integrated strategy on the development of the coal mining industry (ISDCM) need to be developed to facilitate communication among the role players in the coal mining industry.

- The industry should have long-term plans for skills development to address the skills deficiencies in the industry at all times. 
- There should be a shift from road to rail for coal transportation to limit the environmental degradation by trucks.

\subsection{Policy recommendations}

At a policy level the study recommends that the coal mining industry develops an

Integrated Strategy on the Development of Coal Mining (ISDCM) for South Africa. The critical elements of the strategy should be:

- a policy legislative environment;

- working towards a common and shared vision in the industry;

- developing rail and infrastructure;

- developing skills;

- attracting new investors in the industry;

- diversifying ownership of the rail and Transnet; and

- managing the environment.

\section{References}

Abbott, K., Apostolik, R., Goodman, G., Jenner, M., Labhart, G., Maragos, S., May, M., Sunderman, A. D., Parke, J., Stein, J., Wengler, J. \& Went, P. 2009. Foundation of Energy Risk Management: An overview of the energy sector and its physical and financial markets. Global Association of Risk Professional (GARP). Hobken, NJ: John Wiley.

Anglo Coal. 2007. Annual Report.

Bischoff, F. 2009. Coal haulage. IMIESA, October, pp.100-101.

Chamber Of Mines Of South Africa. 2009. Annual Report.

Coal International. 2007. International energy outlook. [Online]. Available at: www.eia.doe.gov/oiaf/ieo/coal.html. Accessed: October, 2008.

Coal Trader. 2013. [Online Magazine]. Accessed: 22 December 2013.

Cooper, D. R. \& Schindler, P. S. 2008. 10th ed. Business Research Methods. New York: McGraw-Hill.

Corbin, J. \& STRAUSS, A. 2008. $3^{\text {rd }}$ ed. Basics of Qualitative Research. Thousand Oaks (CA): Sage.

Crawford, O. 1993. Surface molecular anchoring in microfined liquid crystals near the nematic-smectic-A transition. [Online]. Available at: http://link.aps.org/doi/10.1103/PhysRevE.48.1998. Accessed. 23 April 2009.

Denvers, K.J. \& Frankel, M. 2000. The study design in qualitative research-2: Sampling and Data Collection Strategies. Education for Health, Vol. 13, No. 2, pp. 263-271.

Ehigie, B. O. Ehigie, R. I. 2005. Applying qualitative methods in organisations: A note for industrial/organizational psychologists. The Qualitative Report Volume 10 Number 3 September, pp. 621-638. [Online.] Available at: http://www.nova.edu/ssss/QR/QR103/ehigie.pdf. Accessed: 13 September 2010.

Eskom, Primary Energy Division. 2008. Annual Report.

Eskom. 2009. Annual Report.

Eskom. 2011. Annual Report.

Goddard, W. \& MELVILLE, S. 2005. $2^{\text {nd }}$ ed. Research Methodology (An Introduction). Durban: Juta.

Goussard, L. 2009. New berth 306 expands capacity of RBCT. Civil Engineering, May, p.8.

Lane, T. 2010. Sustainable approach to freight in South Africa. Supply Chain Today, June, pp.32-33.

Kovalainen, A. 2008. Qualitative Methods in Business Research. London: Sage.

Lang, J. 1995. Coal Mining in the Life of South Africa. Cape Town: Jonathan Ball.

Lee, N. \& LINGS, I. 2008. Doing Business Research: A Guide to Theory and Practice. London: Sage.

Lloyd, P. J. 2002. Coal Mining and Environment. Energy Research Institute, University of Cape Town.

Mathu, K. M. 2011. Supply Chain Constraints in South African Coal Mining Industry. Berlin: Lap Lambert.

Mining Weekly. 2012. [Online]. Available at: www.miningweekly.com Accessed: 10 January 2012.

MAXWELL, J. A. 2005. 2nd.ed. Qualitative Research Design: A alternative Approach. Thousand Oaks (CA): Sage.

National Energy Regulator Of South Africa (NERSA). 2008. Annual Report.

National Energy Regulator Of South Africa (NERSA). 2009. Annual Report.

Prevost, X. 2008. Coal mining in South Africa. Inside Mining, pp. 6-9.

Prevost, X. 2009. Undergroung gasification. Inside Mining, September, pp. 7-9

Prevost, X. 2010. A clean future for coal. Inside Mining, April/May, pp. 14-17.

Republic Of South Africa (RSA). Department of Environmental Affairs and Tourism 2006. Environmental Management Plan (EMP). Government Gazette No. 28753. Vol. 490. Pretoria: Government Printer.

Republic Of South Africa (RSA). Department of Minerals and Energy. 2007/2008. South Africa's Mineral Industry (SAMI). Pretoria: Government Printers.

Republic Of South Africa (RSA). Department of Mineral Resources. 2009. Molato (Bana le Basadi ba tlile go tlo rera Molato). 
Johannesburg: Primedia.

Republic Of South Africa (RSA). Department of Mineral Resources. 2010. Mining Licenses Moratorium No. 33511, Vol. 542, Pretoria, 31 August.

Reublic Of South Africa (RSA). Department of Transport. 2006. Interventions to reduce freight and passenger transport costs. Pretoria: Government Printer.

Resource. 2010. Energy usage and climate change. May, pp. 16/18.

Sasol. 2008. Sustainable Development Result.

Sasol 2012 Annual Report

Transnet. 2009. Annual Report.

Transnet. 2013. Annual Report

Van Vuuren, L. 2009. Coal Mining's Impact on Waterberg Under Microscope. The Waterwheel Journal, March/April, p. 14.

Waters. D. 2007. $5^{\text {th }}$ ed. Global Logistics. London: Kogan Page.

Willis, J. W. 2007. Foundations of Qualitative Research (Interpretive and Critical Approach). London: Sage. 